\begin{abstract}
The snowy grouper (Hyporthodus niveatus) is a commercially valuable deepwater grouper that is managed by the South Atlantic Fisheries Management Council. This study updates life history parameters of snowy grouper caught off North and South Carolina from 1979 through 2012 by commercial and research vessels (number of fish sampled: 5314). On the basis of samples collected in 2008-2012, size at age has decreased since the 1990s, and size and age at maturity have increased in comparison with data pooled from the 1980s and 1990s. However, no significant changes in size and age at sex transition were noted between the 2000 s and the 1980s-1990s. This study confirmed that snowy grouper are protogynous and that the spawning season in this region is broader than previously reported. In addition, we found that spawning frequency varied with size and age and was influenced by lunar phase, with most spawning occurring around the new moon. Results indicate that snowy grouper in the study area have started a slow recovery from overfishing.
\end{abstract}

Manuscript submitted 21 November 2018. Manuscript accepted 30 September 2019. Fish. Bull. 117:308-321 (2019).

Online publication date: 24 October 2019. doi: 10.7755/FB.117.4.4

The views and opinions expressed or implied in this article are those of the author (or authors) and do not necessarily reflect the position of the National Marine Fisheries Service, NOAA.

\title{
Temporal changes in the life history of snowy grouper (Hyporthodus niveatus) off North and South Carolina, and factors that influence spawning dynamics
}

\author{
Kevin J. Kolmos (contact author) \\ David M. Wyanski \\ D. Byron White \\ Paulette P. Mikell \\ Email address for contact author: kolmosk@dnr.sc.gov \\ Marine Resources Research Institute \\ South Carolina Department of Natural Resources \\ P.O. Box 12559 \\ Charleston, South Carolina 29422
}

The snowy grouper (Hyporthodus niveatus) is a commercially valuable deepwater species that occurs in the western Atlantic Ocean from Massachusetts to Brazil, including Bermuda, the Bahamas, Cuba, and the Gulf of Mexico (Heemstra et al., 2002), with occasional occurrence off the eastern coast of Canada (Scott and Scott, 1988). This species is thought to be a protogynous hermaphrodite (Moore and Labisky, 1984; Wyanski et al., 2000), but conclusive evidence has not been produced. Along the coast of the southeastern United States, adult snowy grouper are predominantly found on the upper continental slope at depths of 137-259 m, whereas juveniles are more common at shallower depths (Moore and Labisky, 1984). Wyanski et al. (2000) noted a positive correlation between total length (TL) and water depth off North and South Carolina. Most fishing for this species occurs in habitats characterized by rocky ledges, cliffs, and swift currents (Matheson and Huntsman, 1984). Off the southeastern United States, snowy grouper are captured primarily in commercial fisheries with bottom longlines and snapper reels (Parker and Mays, 1998; Wyanski et al., 2000).

Snowy grouper are prone to being overfished (Huntsman et al., 1999) because they are slow growing (Matheson and Huntsman, 1984; Moore and Labisky, 1984; Wyanski et al., 2000) and late maturing, between the ages of 3 and 8 years (Moore and Labisky, 1984; Wyanski et al., 2000). Estimates of their maximum age range from 27 to 29 years (Moore and Labisky, 1984; Wyanski et al., 2000). This range is reasonable, given the maximum age of 27 years reported in a project report for an age validation study (Harris ${ }^{1}$ ) that measured radiocarbon $\left({ }^{14} \mathrm{C}\right)$, from atmospheric testing of nuclear weapons during 1950-1970, in sagittal otolith cores of 21 snowy grouper examined by Wyanski et al. (2000). Results of the validation study were accepted as the best available evidence during the

\footnotetext{
${ }^{1}$ Harris, P. J. 2013. Validation of ages for species of the deepwater snapper/grouper complex off the southeastern coast of the United States. Southeast Data, Assessment, and Review SEDAR36-RD07, 12 p. [Available from website.]
} 
most recent stock assessment (SEDAR, 2013), although the study had the limitations 1 ) of not having a reference chronology from the study area, the southeastern United States, and 2) of small sample sizes during the years that the rate of increase for ${ }^{14} \mathrm{C}$ in the surface waters of the oceans was at its maximum. Periodicity of increment formation was determined indirectly by Wyanski et al. (2000) by using marginal increment analysis.

Landings varied widely during 1981-2005, mostly because of the flexibility of commercial fishermen to shift between fisheries (e.g., from bottom longline for deepwater reef fish to pelagic longline for swordfish in 1984-1985) to optimize earnings (Low et al. ${ }^{2}$ ). This period was characterized by minimal fisheries regulation, given that there were no regulations affecting snowy grouper through 1988 and that the regulations implemented by the South Atlantic Fisheries Management Council after 1988 (e.g., trawling ban, depth restriction for bottom longlining, annual quota, and trip limit) had minimal impact on catches of this species (SEDAR, 2013; $\mathrm{SAFMC}^{3}$ ). In 2009, the South Atlantic Fisheries Management Council allocated 95\% of the total allowable catch to the commercial sector through Amendment 15B to the fishery management plan for snapper and grouper off the coasts of North Carolina, South Carolina, Georgia, and Florida (Federal Register, 2009). Two assessments of the snowy grouper population have been conducted by using the Southeast Data, Assessment, and Review process: a benchmark assessment on snowy grouper in 2004 (SEDAR, 2004) and a standard assessment in 2013 (SEDAR, 2013). The results of the assessment completed in 2004 indicate that the population off the southeastern United States was overfished and was undergoing overfishing, a status that resulted in further reductions in commercial quotas and trip limits to reduce fishing mortality starting in 2006 (SEDAR, 2013). The latest assessment, conducted in 2013, determined that the population was not experiencing overfishing but remained overfished.

Nearly 2 decades have elapsed since the life history of the population of snowy grouper along the Atlantic coast of the southeastern United States was investigated by Wyanski et al. (2000) by using samples collected primarily from the commercial fishery during 1979-1995. By comparing characteristics of the population between the 1980s and 1990s, Wyanski et al. (2000) documented a few indicators of an overfished population, and those signals were confirmed by the benchmark stock assessment in 2004 (SEDAR, 2004). The leading indicators were 1) significant increases in size at age, 2) predominance (81\%) of fish at ages 1-6 in bottom longline samples collected in the 1990s, the majority $(56 \%)$ of which were immature females, and 3) a decrease in mean length of fish landed in the bottom

\footnotetext{
${ }^{2}$ Low, R. A., D. Theiling, and E. B. Joseph. 1987. South Carolina marine fisheries, 1977-1986. South Carolina Wildl. Mar. Res. Dep., Tech. Rep. 67, 78 p. [Available from website.]

${ }^{3}$ SAFMC (South Atlantic Fishery Management Council). 2019. Snapper grouper-fishery management plan. [Available from website, accessed February 2019.]
}

longline fishery from $65-80 \mathrm{~cm}$ TL to 50-60 mm TL without any notable change in depth of capture.

Updates of life history parameters for snowy grouper are needed to fill existing information gaps and provide critical data for stock assessments in support of the sustainable management of this species. Reproductive parameters such as sex composition need further investigation because of a small sample size in previous studies; the analysis by Wyanski et al. (2000) included only 82 specimens collected during 1993-1994, none of which were $>900 \mathrm{~mm}$ TL. The results of this study provide updated estimates of life history parameters, such as size at age, age at maturity, spawning seasonality, and age at sex transition. We discuss the potential effects of management measures implemented since 2006 on the life history parameters of the population of snowy grouper off the southeastern United States. Our histological samples were also examined for evidence to confirm that the snowy grouper is a protogynous hermaphrodite and to investigate the effect of age, size, and lunar phase on spawning.

\section{Materials and methods}

\section{Sampling}

During 1979-2012, snowy grouper were obtained from commercial boats, research vessels, and recreational charter boats, primarily off North and South Carolina. Fisheryindependent samples of reef fish species were collected during cruises conducted as part of the Marine Resources Monitoring Assessment and Prediction (MARMAP) program, the Southeast Area Monitoring and Assessment Program-South Atlantic (SEAMAP-SA), and the Southeast Fishery-independent Survey (SEFIS) with bottom longlines, Kali poles (an off-bottom longline; Russell et al., 1988), snapper reels, rods and reels, and chevron traps (Collins, 1990; Smart et al. ${ }^{4}$ ). These 3 sampling efforts represent a collaborative survey known as the Southeast Reef Fish Survey, which samples fish on natural reefs from Cape Hatteras, North Carolina, to St. Lucie Inlet, Florida. Kali poles were used only during sampling in the 1980s, and sampling prior to 2010 was conducted solely by the MARMAP program. The SEAMAP-SA and SEFIS began sampling in 2008 and 2010, respectively, and use chevron traps and rods and reels to complement sampling done by the MARMAP program with the same gears.

In the years since the study by Wyanski et al. (2000), the MARMAP program acquired specimens of snowy grouper in 2008-2009 through a Cooperative Research Program grant it received from the National Marine Fisheries Service in partnership with a commercial bottom longline fisherman. From this fisherman's vessel, 1078 snowy grouper

\footnotetext{
${ }^{4}$ Smart, T. I., M. J. M. Reichert, J. C. Ballenger, W. J. Bubley, and D. M. Wyanski. 2016. Overview of sampling gears and standard protocols used by the Southeast Reef Fish Survey and its partners. Southeast Data, Assessment, and Review SEDAR50-RD20, $14 \mathrm{p}$. [Available from website.]
} 
were captured at $32.5-33.0^{\circ} \mathrm{N}$ and depths of $172-251 \mathrm{~m}$, an area similar $\left(32.3-33.9^{\circ} \mathrm{N}\right.$ and depths of $\left.155-302 \mathrm{~m}\right)$ to that fished by 3 longline fishermen who captured specimens (number of fish sampled $[n]=1361$ ) for the earlier study (see figure 1 in Wyanski et al., 2000).

After collection, whole snowy grouper were weighed to the nearest gram and the maximum TL (from the anterior-most point on the head to the tip of the caudal fin with lobes compressed) and standard length were measured to the nearest millimeter. The left sagittal otolith was removed and stored dry prior to processing (the right sagitta also was removed when time permitted). Samples of gonad tissue were removed and fixed in 10-11\% seawater-formalin for later histological processing.

\section{Age and growth}

Each otolith was embedded in paraffin (1979-1985) or an epoxy resin (1993-2012) and sectioned (thickness: 0.5-0.7 $\mathrm{mm}$ ) along a dorsoventral plane through the focus with a single high-concentration diamond wheel on a Buehler ${ }^{5}$ IsoMet Low Speed Saw (Buehler, Lake Bluff, IL). Otolith sections were mounted on glass slides with thermoplastic or a liquid mounting medium and examined under a Nikon dissecting microscope (Nikon Corp., Tokyo, Japan) (magnification: 7.5-63x) with reflected and transmitted light. Sample sections read before 1996 were covered with cedar wood oil prior to examination.

Otolith sections were examined by 2 readers independently and reexamined jointly when differences in age estimation occurred; aging was done without knowledge of specimen length and date or location of capture (Harris et al., 2002). If disagreement on age persisted, the specimen was eliminated from age and growth analyses. Age analyses were based on counts of annual increments (one opaque and one translucent zone). We examined 2364 specimens from 1996 through 2012 and used samples from Wyanski et al. (2000) as a historical data set $(n=2263)$.

\section{Reproduction}

Histological processing of gonadal tissues followed standard hematoxylin and eosin techniques. The posterior portion of each gonad was fixed for 7-14 $d$ in a $10-11 \%$ seawater-formalin solution buffered with marble chips then transferred to 50\% isopropanol for 7-14 d. Reproductive tissue was processed in automated tissue processors and blocked in paraffin. Three transverse sections (thickness: $6-8 \mu \mathrm{m}$ ) were cut from each sample with a rotary microtome, mounted on glass slides, stained with double-strength Gill's hematoxylin, and counterstained with Eosin Y. Sections were viewed under a Nikon compound microscope (Nikon Corp.) (magnification: 20-400x) by 2 readers without knowledge of specimen length or age

\footnotetext{
${ }^{5}$ Mention of trade names or commercial companies is for identification purposes only and does not imply endorsement by the National Marine Fisheries Service, NOAA.
}

and date or location of capture. The readers independently determined sex and reproductive phase by using histological criteria described by Wyanski et al. (2000) and Harris et al. (2004); terminology follows a recent review by Brown-Peterson et al. (2011). If the assessments differed between readers for a section, it was viewed jointly by the readers. A specimen was eliminated from reproductive analyses when disagreement on its sex or reproductive phase persisted. To ensure that inactive females were assigned correctly to either the immature phase or the regenerating phase, the length-frequency histograms of suspected immature and early developing or regenerating females were compared with the histograms for females with evidence of definite maturity (i.e., those that were developing, spawning capable, or regressing). The criteria put forward by Sadovy and Shapiro (1987) and Sadovy de Mitcheson and Liu (2008) were used for the diagnosis of hermaphroditism.

Specimens with developing, spawning-capable, regressing, or regenerating gonads were considered sexually mature. Females of uncertain maturity were excluded from all reproductive analyses (Wyanski et al., 2000). Juvenile females were excluded from sex composition analyses to restrict data to the adult population (Coleman et al., 1996), and specimens undergoing sex transition (female to male) were considered males, unless noted, because these specimens would likely have spawned as males in the next spawning season (Sadovy and Shapiro, 1987). In addition, sex composition analyses were restricted to data from gear types that effectively sample the adult population (i.e., Kali poles and longlines). Females were considered spawners if they possessed maturing oocytes (i.e., fusing of yolk globules, germinal vesicle migration and breakdown, and hydration), ovulated eggs, or postovulatory follicle complexes. Spawning indicators were based on stages that are thought to last approximately $60 \mathrm{~h}-12 \mathrm{~h}$ for oocyte maturation and hydration and $48 \mathrm{~h}$ for postovulatory follicle complexes (Hunter and Goldberg, 1980; Fitzhugh et al., 1993). We use spawning frequency and spawning interval as defined in LowerreBarbieri et al. (2011). Spawning proportion, called spawning fraction by Lowerre-Barbieri et al. (2011), is the proportion of adult females that were spawning daily. Values of spawning proportion were proportionally reduced to a $24-\mathrm{h}$ period. Batches were determined by multiplying the proportion of spawners by duration of the spawning season.

Lunar phase analyses were performed to determine if the lunar cycle influenced the periodicity of spawning in snowy grouper. We combined all samples from all gear types that were collected during 1982-2012 and had stamps with the exact date and time of their collection. The new moon day was defined as day 0 , and the full moon was defined as day 15 . Individual specimens $(n=371)$ were given a lunar day based on the new moon date for that month and year, their time of capture, and their reproductive phase. For specimens undergoing oocyte maturation (excluding hydration), lunar day was calculated as capture date $+1 \mathrm{~d}$ because spawning would have most likely taken 
place in the $24 \mathrm{~h}$ after capture. For specimens with vitellogenic oocytes or with hydrated oocytes, lunar day was equal to their date of capture. For specimens with postovulatory complexes, lunar day was determined to be the capture date $-1 \mathrm{~d}$ because spawning would have occurred in the 24-48 $\mathrm{h}$ prior to capture. The effect of lunar day on spawning probability (no. of spawners to no. of active females, i.e., presence of vitellogenic oocytes) was analyzed by using a generalized additive model (GAM), with binomial error distribution and logit link function. No other covariates were included in the model.

\section{Analyses}

Analyses were completed with statistical software R, vers. 3.0.2 (R Core Team, 2013), Microsoft Excel 2013 (Microsoft Corp., Redmond, WA), and SAS (vers. 9.4; SAS Institute Inc., Cary, NC), and results were deemed significant if $P<0.05$. Mean values of length, age, and length at age were compared between periods by using analysis of variance. All lengths in the text refer to maximum TL. Gear selectivity was assessed with density analysis of TL to determine how data from various gear types could be pooled for temporal comparisons related to age and growth; comparisons focused on 2 or 3 of the following periods: 1982-1985, 1993-1994, and 2008-2012 (hereafter referred to as the $1980 \mathrm{~s}, 1990 \mathrm{~s}$, and 2000s). Density analyses and the Kolmogorov-Smirnov test were used to compare length and age distributions between periods. Nonlinear regression analysis was used to fit the von Bertalanffy growth function (von Bertalanffy, 1938) to length at age data by period. Following Wyanski et al. (2000), TLs were weighted by the inverse of the number of fish at each age, by period and overall, to moderate the effect of large and small sample sizes on the estimates of growth parameters from the von Bertalanffy growth function.

All available reproductive samples from all gears were pooled for reproductive analyses, primarily to increase sample size. Pooling data from the 1980 s and 1990 s was necessary to increase sample size for the temporal aspect of analyses of sexual maturity and sex transition. Additional samples $(n=85)$ from the period 1979-1981 were used in maturity and spawning proportion analyses. For maturity analyses, pooling data over decades also ensured that more specimens, especially those within the range of size and age at which maturity was reached, were included in the temporal comparison (1980s and 1990s versus 2000s); these smaller specimens are caught more frequently with chevron traps, which were not used in the $1980 \mathrm{~s}$. To estimate length at $50 \%$ maturity $\left(L_{50, \text { mat }}\right)$ and age at $50 \%$ maturity $\left(A_{50, \text { mat }}\right)$, a generalized linear model with a logit, probit, c-log, or Cauchy link was fit to maturity data in RStudio, vers. 3.5.2 (RStudio, 2018); length and increment data were not binned. The same analyses were run to estimate the length $\left(L_{50, \text { male }}\right)$ and age $\left(A_{50, \text { male }}\right)$ at $50 \%$ sex transition to male. The selected model had the lowest Akaike information criterion (Akaike, 1973). Significance was evaluated at the $5 \%$ error level by using the likelihood ratio chi-square $\left(\chi^{2}\right)$ test. In spawning analyses, data for sizes of fish from the spawning season (AprilSeptember) were grouped into 100-mm-TL bins starting from 501-600 mm TL and ending with a terminal group of $\geq 901 \mathrm{~mm}$ TL; analyses were performed overall and within months. The same spawning analyses were performed on ages of fish from the spawning season and grouped into 2-year bins starting from ages 3-4 and ending with a terminal group of ages $\geq 11$ years. Lunar effects on spawning were investigated with a GAM.

\section{Results}

\section{Age and growth}

All specimens $(n=5314)$ were collected between $29.66^{\circ} \mathrm{N}$ and $34.73^{\circ} \mathrm{N}$ and at depths of $18-302 \mathrm{~m}$, but only 7 specimens were collected south of $31^{\circ} \mathrm{N}$. We aged 2192 specimens during 1996-2012, making our total number of aged specimens 4342 when adding historical data from Wyanski et al. (2000). Ages in the combined data set ranged from 1 to 35 years, and lengths ranged from 130 to $1137 \mathrm{~mm}$ TL. Males ranged in age from 6 to 32 years (mean: 13.0 years [standard error (SE) 0.5]; median: 12 years) and in size from 620 to $1090 \mathrm{~mm}$ TL (mean: $899 \mathrm{~mm}$ TL [SE 6.5]; median: $901 \mathrm{~mm}$ TL), whereas females ranged in age from 1 to 35 years (mean: 6.7 years [SE 0.1]; median: 6 years) and in size from 208 to $1113 \mathrm{~mm}$ TL (mean: $611 \mathrm{~mm}$ TL [SE 2.9]; median: $619 \mathrm{~mm}$ TL). Transitional specimens ranged in age from 5 to 12 years (mean: 8.4 years [SE 0.6]; median: 8 years) and in size from 627 to $895 \mathrm{~mm}$ TL (mean: $803 \mathrm{~mm}$ TL [SE 18.3]; median: $826 \mathrm{~mm}$ TL).

To determine whether to combine length and age data for the 4 prevalent hook-and-line gear types, a density analysis was performed on TL by gear type for all periods combined (Fig. 1). Results indicate that the overall size range of snowy grouper was similar among gear types, but snapper reels caught a higher proportion of individuals $<450 \mathrm{~mm}$ TL than the other gear types because this gear is fished in shallower depths and catches smaller fish (Wyanski et al., 2000). Given the notable difference in the size selectivity of snapper reels, data from the remaining 3 gear types (long bottom longline, short bottom longline, and Kali pole) were combined, because of their relatively similar size selectivity, and used in further analyses of age and growth (Table 1). Another reason for combining the data is the similarity of the fishing hook sizes (\#5-7) used in each longline gear and the Kali pole gear (Russell et al., 1988; Harris et al., 2004; Smart et al. ${ }^{4}$ ). The inclusion of data from only one period for short bottom longlines (2000s) and Kali poles (1980s) in the pooled data did not influence the temporal comparisons because a Kolmogorov-Smirnov test of data from long bottom longlines between each period was significant $(P<0.001)$ for size and age, indicating that the differences between periods are explained by time, not gear type. 


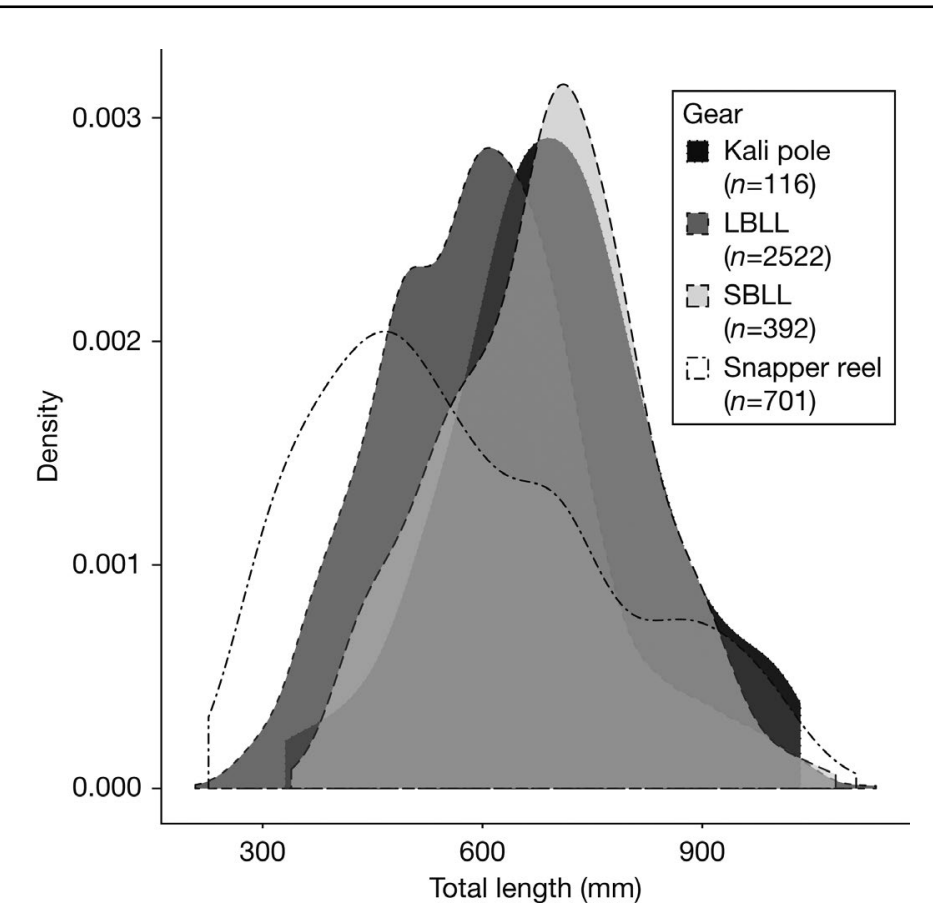

Figure 1

Density plots of total length for all snowy grouper (Hyporthodus niveatus) captured during 1979-2012, off North and South Carolina, with 4 gear types: Kali pole, long bottom longline (LBLL), short bottom longline (SBLL), and snapper reel. The unit for density is the relative proportion of fish that were caught with a particular gear type. $n=$ number of fish sampled.

The results of analyses of size and age distributions, mean length, mean age, and size at age all indicate significant differences among periods. Density plots comparing TL by period show similarities in overall size range; however, a Kolmogorov-Smirnov test revealed that the size, as well as age, distributions were significantly different among periods $(P<0.001$; Fig. 2, A and B). In addition, both mean TL and mean age differed significantly among periods (Tukey's honestly significant difference: adjusted $P<0.001)$. The mean size and age of fish increased from $584 \mathrm{~mm}$ TL and 5.5 years in the $1990 \mathrm{~s}$ to $632 \mathrm{~mm}$ TL and 6.8 years in the 2000s (Table 2); however, these values are noticeably less than the means of $714 \mathrm{~mm}$ TL and 11.8 years for samples from the 1980s. Size at age of specimens caught only with bottom longline gear (long and short) was significantly different between the 2 recent periods, the 1990 s versus the 2000 s, for ages $3-12$, except it remained the same for age 4 (minimum $n>20, P<0.05$ ). A significant decrease in size at age was detected for age 3 and ages $6-12$, with size at age increasing only for age 5 (Table 3 ).

The analyses of von Bertalanffy growth parameters revealed some differences among periods (Fig. 3, Table 4). Growth curves for the 1990s and 2000 s had the same growth coefficient $(k=0.12)$, with a slight decrease of the asymptotic length $\left(L_{\infty}\right)$ in the 2000s. The 1980s had the lowest $k$ value (0.085) and the lowest $L_{\infty}$ (1004 mm TL) (Table 4).

\section{Sexual pattern}

Conclusive evidence for the diagnosis of sexual pattern has not been presented previously for snowy grouper. We confirmed that this species is a protogynous hermaphrodite by the capture of individuals having gonads with 1$) \alpha$-stage atresia in vitellogenic oocytes within developing male tissue and 2) sperm sinuses in the gonadal wall (Fig. 4). The results of

\section{Table 1}

Number of snowy grouper (Hyporthodus niveatus) for which otoliths and gonads were examined per period by gear type. Specimens were caught off North and South Carolina as part of fishery-independent (FI) and fishery-dependent (FD) surveys during 3 periods: 1982-1985, 1993-1994, and 2008-2012. Values in the "Other" row represent the total numbers combined for the following gear types: hook and line, University of Rhode Island high-rise trawl, blackfish trap, experimental trap, Florida trap, and unknown.

\begin{tabular}{|c|c|c|c|c|c|c|c|}
\hline \multirow[b]{3}{*}{ Gear type } & \multirow[b]{3}{*}{ Source } & \multicolumn{6}{|c|}{ Number of fish } \\
\hline & & \multicolumn{3}{|c|}{ Otoliths examined } & \multicolumn{3}{|c|}{ Gonads examined } \\
\hline & & $1980 \mathrm{~s}$ & $1990 \mathrm{~s}$ & $2000 \mathrm{~s}$ & $1980 \mathrm{~s}$ & $1990 \mathrm{~s}$ & $2000 \mathrm{~s}$ \\
\hline \multirow[t]{2}{*}{ Long bottom longline } & FI & 53 & 0 & 5 & 70 & 0 & 5 \\
\hline & FD & 22 & 1215 & 999 & 0 & 146 & 1074 \\
\hline Short bottom longline & FI & 0 & 0 & 379 & 0 & 0 & 389 \\
\hline Kali pole & FI & 94 & 0 & 0 & 82 & 0 & 0 \\
\hline \multirow{2}{*}{ Snapper reel } & FI & 115 & 1 & 0 & 204 & 1 & 0 \\
\hline & FD & 57 & 308 & 10 & 1 & 22 & 0 \\
\hline Chevron trap & FI & 0 & 78 & 83 & 0 & 77 & 82 \\
\hline Other & FI & 10 & 2 & 15 & 11 & 2 & 16 \\
\hline Total & & 351 & 1604 & 1491 & 368 & 248 & 1566 \\
\hline
\end{tabular}



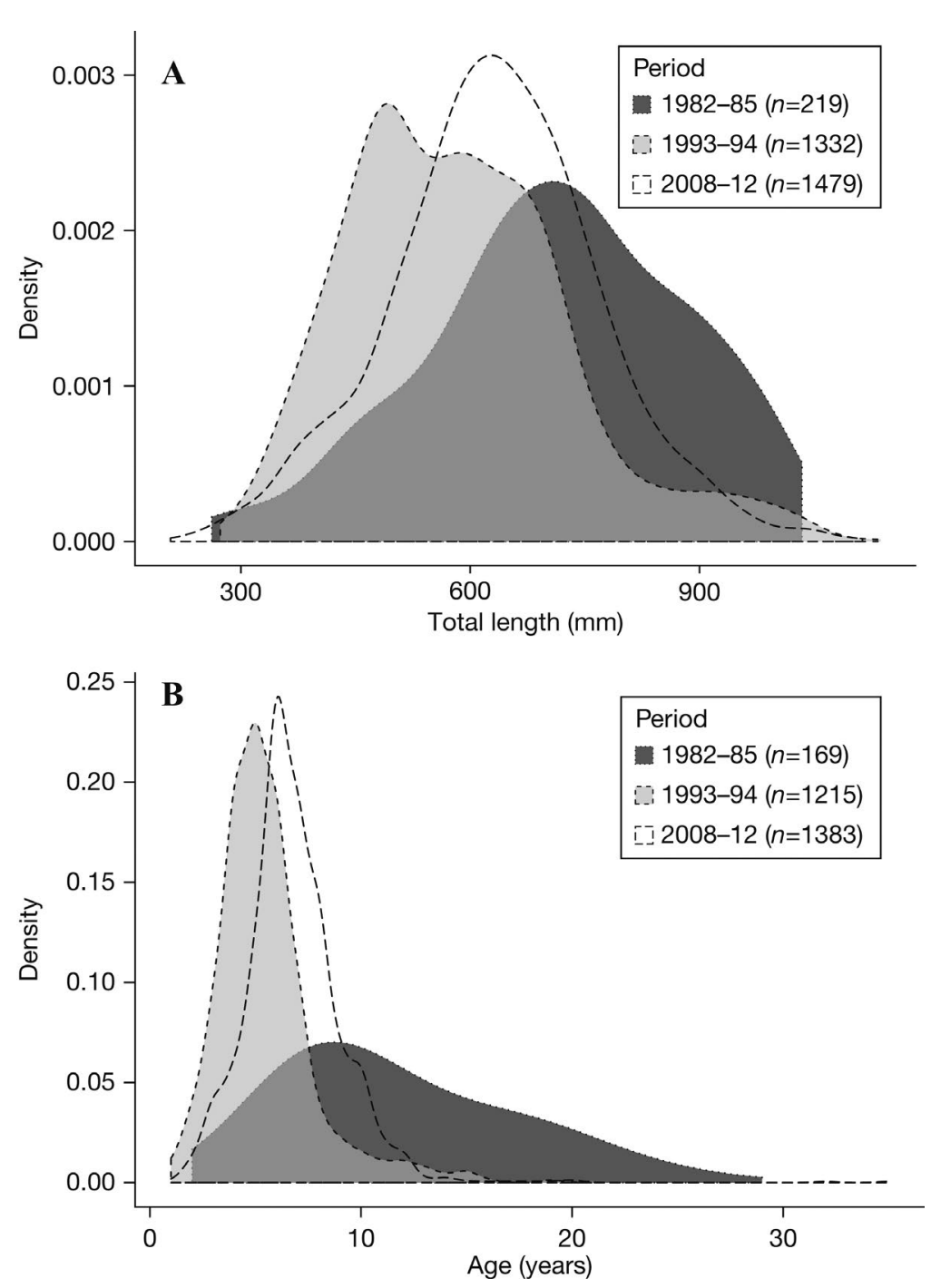

Figure 2

Density plots of (A) total length and (B) age by period for all snowy grouper (Hyporthodus niveatus) captured off North and South Carolina during 3 periods: 1982-1985, 1993-1994, and 2008-2012. Ages are counts of annual increments (one opaque and one translucent zone) from otolith readings. The unit for density is the relative proportion of fish that were caught during a particular period. $n=$ number of fish sampled.

comparisons of the age distribution and the median age of females and males (transitional specimens excluded) from all years also indicate protogyny (Fig. 5). Of the 16 fish that were older than age $20,31 \%$ were female and $69 \%$ were male. The median age of females was 6 years, half the median age of 12 years for males.

\section{Maturity and sex composition}

We examined histological sections of gonad tissue from 1566 snowy grouper collected during 2008-2012, making our total number of histological samples 2324 when adding historical data from Wyanski et al. (2000).
Correct assignment of females from the period 2008-2012 to the immature and regenerating reproductive phases was indicated by the presence of only 5 specimens in the regenerating phase (457-517 $\mathrm{mm}$ TL) that were smaller than the total length $(525 \mathrm{~mm} \mathrm{TL})$ of the smallest definitely mature specimen (i.e., specimen in the developing, spawning-capable, or regressing phases). There were 19 specimens $<525 \mathrm{~mm}$ TL (1.3\% of 1467 females examined) that could not be definitively categorized as immature or regenerating.

Female size and age at maturity were assessed for the overall data set (i.e., all gears and all years) and by period. The smallest mature female was $457 \mathrm{~mm}$ TL, whereas the largest immature female was $787 \mathrm{~mm}$ TL. In the observed data, gonads in a reproductive phase indicative of sexual maturity were present in $4 \%$ of females at age 3 , in $44 \%$ at age 5 , in $75 \%$ at age 7 , and in $100 \%$ at ages $>13$ years. The $L_{50 \text {, mat }}$ was $578 \mathrm{~mm}$ TL (logit link: $n=1853,95 \%$ confidence interval [CI] 475-702 mm TL). Because of low sample sizes, data from the 1980 s and 1990s were combined to conduct a temporal analysis of $L_{50 \text {, mat }}$. There was a significant increase in $L_{50, \text { mat }}$ from $529 \mathrm{~mm}$ TL (logit link: $n=564,95 \%$ CI $314-893 \mathrm{~mm}$ TL) in the 1980s and 1990s to $596 \mathrm{~mm}$ TL (logit link: $n=1289,95 \%$ CI $474-747 \mathrm{~mm}$ TL) in the $2000 \mathrm{~s}$ ( $\chi^{2}$ test: $P<0.001$; Fig. 6A). The overall youngest mature female was age 3 , whereas the oldest immature female was age 13 . The $A_{50 \text {, mat }}$ was 5.5 years (Cauchy link: $n=1637$, 95\% CI $4.0-7.6$ years). To conduct a temporal analysis of $A_{50, \text { mat }}$, data from the 1980s and 1990s were again combined because of low sample sizes. There was a significant increase in $A_{50, \text { mat }}$ from 5.0 years (logit link: $n=425$, $95 \%$ CI $3.2-7.6$ years) in the 1980 s and 1990 s to 5.8 years (logit link: $n=1212,95 \%$ CI $3.2-7.6$ years) in the $2000 \mathrm{~s}$ ( $\chi^{2}$ test: $P<0.001$ ) (Fig. $6 \mathrm{~B}$ ).

Trends in length and age at sex transition to male were examined for the overall data set and by period. The overall estimates of $L_{50 \text {, male }}$ and $A_{50 \text {, male }}$ for all gear types were $886 \mathrm{~mm}$ TL (logit link: $n=2038,95 \%$ CI $688-1143 \mathrm{~mm}$ TL) and 17.0 years (probit link: $n=1755,95 \%$ CI $14.0-21.9$ years), respectively. Estimates of $L_{50}$, male were similar between periods, $880 \mathrm{~mm}$ TL in the $1980 \mathrm{~s}$ and $1990 \mathrm{~s}$ combined (logit link: $n=657,95 \%$ CI $593-1309 \mathrm{~mm}$ ) and $894 \mathrm{~mm}$ TL in the 2000s (logit link: $n=1360,95 \%$ CI $633-1269 \mathrm{~mm}$ TL; $\chi^{2}$ test: $P=0.52$ ). There was a decrease in $A_{50 \text {, male }}$ from 18.0 years (logit link: $n=473,95 \%$ CI $11.8-27.8$ years) in 


\section{Table 2}

Summary statistics for the total lengths and ages of snowy grouper (Hyporthodus niveatus) collected off North and South Carolina during 3 periods: 1982-1985, 19931994, and 2008-2012. Ages are counts of annual increments (one opaque and one translucent zone) from otolith readings. Data were combined for 3 gear types: Kali pole, long bottom longline, and short bottom longline. $n=$ number of fish examined; $\mathrm{SE}=$ standard error of the mean.

\begin{tabular}{|c|c|c|c|c|c|c|c|c|}
\hline \multirow[b]{2}{*}{ Period } & \multicolumn{4}{|c|}{ Total length (mm) } & \multicolumn{4}{|c|}{ Age } \\
\hline & $n$ & Median & Mean & $\mathrm{SE}$ & $n$ & Median & Mean & $\mathrm{SE}$ \\
\hline $1980 \mathrm{~s}$ & 219 & 720 & 714 & 11 & 169 & 10 & 11.8 & 0.4 \\
\hline $1990 \mathrm{~s}$ & 1332 & 572 & 584 & 4 & 1215 & 5 & 5.5 & 0.1 \\
\hline $2000 \mathrm{~s}$ & 1479 & 634 & 632 & 4 & 1383 & 7 & 6.8 & 0.1 \\
\hline All periods & 3030 & 614 & 617 & 3 & 2767 & 6 & 6.6 & 0.1 \\
\hline
\end{tabular}

\section{Table 3}

Mean sizes at age of snowy grouper (Hyporthodus niveatus) collected off North and South Carolina during 3 periods: 1982-1985, 1993-1994, and 2008-2012, by age and period. Data were combined for 3 gear types: Kali pole, long bottom longline (LBLL), and short bottom longline (SBLL). Also included are results of analysis of variance conducted for mean total length at age between the 1990s and 2000s by using data for LBLL and SBLL gear. Ages are counts of annual increments from otolith readings. $\mathrm{SE}=$ standard error of the mean; $n=$ number of fish examined.

\begin{tabular}{|c|c|c|c|c|c|c|c|c|c|c|c|}
\hline \multirow[b]{3}{*}{ Age } & \multicolumn{9}{|c|}{ LBLL, SBLL and Kali pole } & \multirow{2}{*}{\multicolumn{2}{|c|}{$\frac{\text { LBLL and SBLL }}{1990 \text { s vs. } 2000 \mathrm{~s}}$}} \\
\hline & \multicolumn{3}{|c|}{$1982-1985$} & \multicolumn{3}{|c|}{ 1993-1994 } & \multicolumn{3}{|c|}{$2008-2012$} & & \\
\hline & Mean & $\mathrm{SE}$ & $n$ & Mean & $\mathrm{SE}$ & $n$ & Mean & $\mathrm{SE}$ & $n$ & $P$-value & $n$ \\
\hline 2 & 418 & - & 1 & 381 & 8.9 & 46 & 361 & 19.9 & 16 & 0.296 & 62 \\
\hline 3 & 423 & 96.0 & 2 & 427 & 6.2 & 111 & 396 & 9.7 & 61 & 0.004 & 172 \\
\hline 4 & 393 & 127.5 & 2 & 492 & 4.5 & 250 & 500 & 13.7 & 78 & 0.520 & 328 \\
\hline 5 & 515 & 36.5 & 8 & 564 & 4.5 & 286 & 582 & 7.5 & 163 & 0.025 & 449 \\
\hline 6 & 523 & 39.4 & 11 & 627 & 5.0 & 241 & 612 & 4.4 & 364 & 0.029 & 605 \\
\hline 7 & 604 & 23.4 & 19 & 673 & 6.6 & 126 & 648 & 5.6 & 262 & 0.006 & 388 \\
\hline 8 & 640 & 26.7 & 19 & 739 & 12.2 & 42 & 689 & 6.9 & 201 & 0.002 & 243 \\
\hline 9 & 644 & 28.2 & 7 & 818 & 19.2 & 27 & 725 & 11.5 & 87 & $<0.001$ & 114 \\
\hline 10 & 729 & 17.1 & 18 & 909 & 14.5 & 19 & 770 & 10.1 & 85 & $<0.001$ & 104 \\
\hline 11 & 678 & 27.3 & 9 & 905 & 30.3 & 13 & 821 & 20.1 & 27 & 0.024 & 40 \\
\hline 12 & 760 & 31.3 & 11 & 932 & 23.5 & 14 & 823 & 23.8 & 23 & 0.004 & 37 \\
\hline
\end{tabular}

the 1980 s and 1990 s to 13.9 years (logit link: $n=1282$, 95\% CI 9.6-20.8 years) in the 2000s, but differences were not significant ( $\chi^{2}$ test: $P=0.92$ ). The proportion of males (including transitional specimens) in all samples was 0.12. A temporal analysis, restricted to 3 gear types (long bottom longline, short bottom longline, and Kali pole), of sex composition revealed that few males were present at lengths $\leq 800 \mathrm{~mm}$ TL in samples across 3 decades, with the proportions of males at that size ranging from 0.00 to 0.06 (Table 5). In samples from the 2000s, an increasing trend in the proportions of males at larger sizes was observed, with values ranging from 0.32 at lengths of $801-900 \mathrm{~mm}$ TL to 0.86 at lengths of 1001-1100 mm TL. These values were similar to, although slightly lower than, those for samples from the 1980s.

\section{Spawning}

Spawning season was determined by comparing dates of capture to the presence of spawning indicators. Samples collected during 2008-2012 revealed a similar spawning season (April through September) to that reported by Wyanski et al. (2000). Five specimens with evidence of imminent (oocyte maturation) or recent spawning (postovulatory complexes) were collected in October 2008 and in January and March 2009, indicating that the 


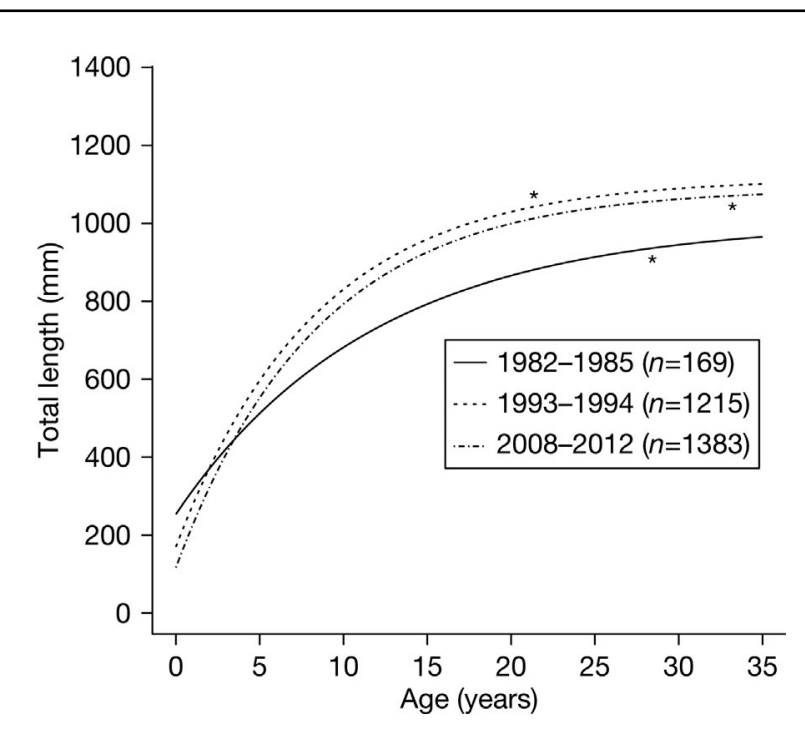

Figure 3

The von Bertalanffy growth curves for snowy grouper (Hyporthodus niveatus) captured off North and South Carolina during 3 periods: 1982-1985, 1993-1994, and 20082012. Ages are counts of annual increments from otolith readings. The asterisk $(*)$ above each line denotes the oldest fish aged for that period. $n=$ number of fish examined.

\section{Table 4}

Mean estimates of parameters of the von Bertalanffy growth function, the theoretical maximum length $\left(L_{\infty}\right)$, growth coefficient $(k)$, and initial condition parameter $\left(t_{0}\right)$, for snowy grouper (Hyporthodus niveatus) collected off North and South Carolina during 3 periods: 1982-1985, 1993-1994, and 2008-2012. Data were combined for 3 gear types: Kali pole, long bottom longline, and short bottom longline. $n=$ number of fish examined; $\mathrm{SE}=$ standard error of the mean.

\begin{tabular}{lrrrcccc}
\hline Period & $n$ & $L_{\infty}$ & SE & $k$ & SE & $t_{0}$ & SE \\
\hline $1980 \mathrm{~s}$ & 169 & 1004 & 47 & 0.085 & 0.015 & -3.44 & 1.03 \\
$1990 \mathrm{~s}$ & 1215 & 1115 & 12 & 0.120 & 0.004 & -1.37 & 0.12 \\
$2000 \mathrm{~s}$ & 1383 & 1090 & 10 & 0.119 & 0.004 & -0.95 & 0.12 \\
All periods & 2767 & 980 & 5 & 0.126 & 0.003 & -1.85 & 0.13 \\
& & & & & & & \\
\hline
\end{tabular}

potential spawning season is from late January through early October.

Spawning activity varied by size and age. An analysis of spawning proportion in relation to TL revealed that there was less spawning in the smallest fish (501$600 \mathrm{~mm} \mathrm{TL}$ ), with this length bin having the lowest proportion of spawners (0.06), a generally shorter spawning season (2-5 weeks), and the smallest number of batches (8) compared with those of larger fish (Table 6). Spawning proportion and number of batches increased with fish length, reaching the maximum values of 0.18 in the bin for fish $\geq 901 \mathrm{~mm}$ TL and 27 batches in the bin for fish $801-900 \mathrm{~mm}$ TL. There was a slight decrease to 24 batches at lengths $\geq 901 \mathrm{~mm}$ TL, possibly because of the shorter spawning season in this size class. For all length bins, the lowest spawning proportions occurred at the beginning (April) and end (September) of the spawning season (Fig. 7A). In addition, the positive relationship between spawning proportion and fish length was evident throughout the spawning season.

Analyses also were completed on effects of age on spawning proportion (Table 7). The youngest snowy grouper (ages $3-4$ ) had the lowest proportion of spawners (0.03), with the proportion increasing to 0.11 at ages 5-6 and leveling out to $0.14-0.15$ at ages $>6$ years. Because the spawning season also is shorter at younger ages, spawning frequency similarly increased, from 15 batches at ages 5-6 to 22-24 batches at older ages; the number of batches for ages 3-4 could not be calculated as a result of the small sample size. Spawning interval decreased slightly with age, from $9 \mathrm{~d}$ at ages 5-6 to $7 \mathrm{~d}$ at older ages. Similar to results from analyses of the length data, a general pattern of the lowest values of spawning proportion occurring at the beginning (April) and end (September) of the spawning season was observed for snowy grouper at ages $>5$ years (Fig. 7B). In the youngest age bin (3-4 years), spawners were captured only in July.

Spawning patterns indicate a lunar periodicity (GAM: $n=371 ; \chi^{2}$ test: $91.3, P \leq 0.001$ ). Overall, the GAM explained $26.7 \%$ of the deviance in spawning probability (coefficient of multiple determination $\left[R^{2}\right]=0.312$ ). On the basis of occurrence of spawners, spawning was least likely to occur around the full moon period (lunar days 15-18), whereas most spawning occurred between the waning crescent and waxing crescent phases, with a peak during the period of the new moon (lunar days 0-3 and 22-28) (Fig. 8). No adult female fish were collected on lunar days $6-8$.

\section{Discussion}

The results of analyses of life history parameters support the conclusion of the most recent stock assessment that the population of snowy grouper off North and South Carolina has started a slow recovery from an overfished status: spawning stock biomass (SSB) is less than SSB at maximum sustainable yield (MSY). Results from analyses of age and growth, sex composition, and maturity all indicate a positive response to regulations to reduce fishing effort (i.e., further reductions in trip limit and annual quota for commercial sector) that were implemented after the previous assessment (SEDAR, 2013). Wyanski et al. (2000) proposed that the plasticity observed in growth between the early 1980s and the period 1993-1994 represented a density-dependent response to an increase in fishing mortality. Given that regulations implemented since 1994 , and especially since 2006 , have reduced fishing mortality, examination of life history samples collected 


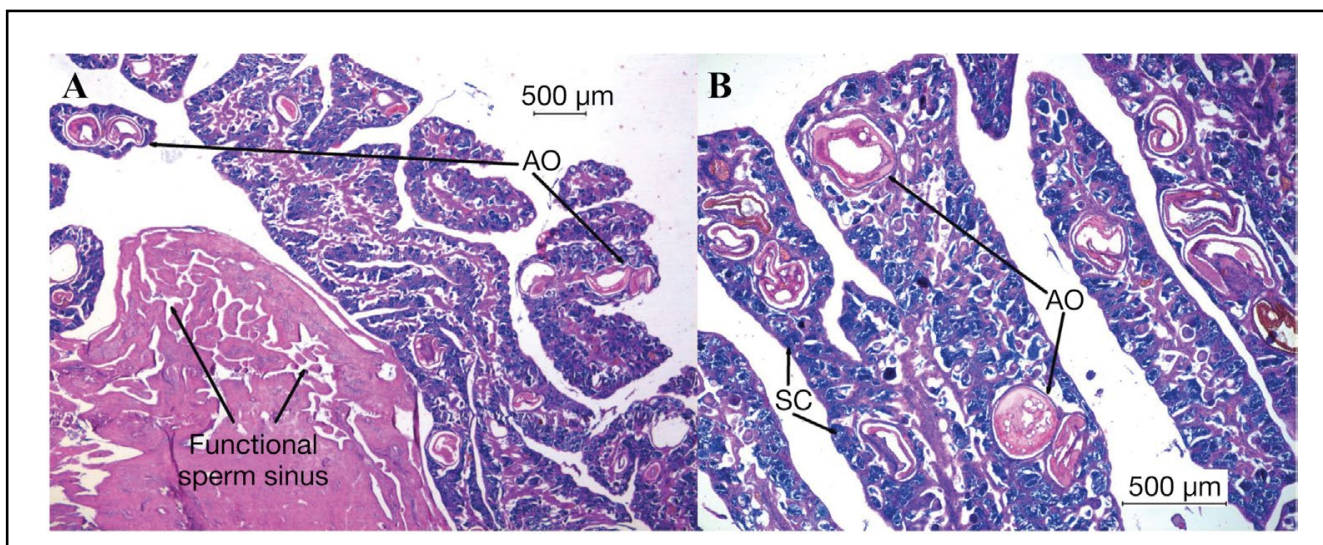

Figure 4

Images of gonadal tissue from a specimen of snowy grouper (Hyporthodus niveatus) that was transitioning from female to male, showing (A) functional sperm sinuses and atretic oocytes (microscope magnification: $20 \times$ ) and (B) atretic oocytes within spermatogenic tissue (microscope magnification: $40 \times$ ). This specimen was captured on 27 August 2008 off South Carolina at a total length of $834 \mathrm{~mm}$ and age of 7 years. $\mathrm{AO}=\alpha$-stage atretic oocyte; $\mathrm{SC}=$ spermatocytes.

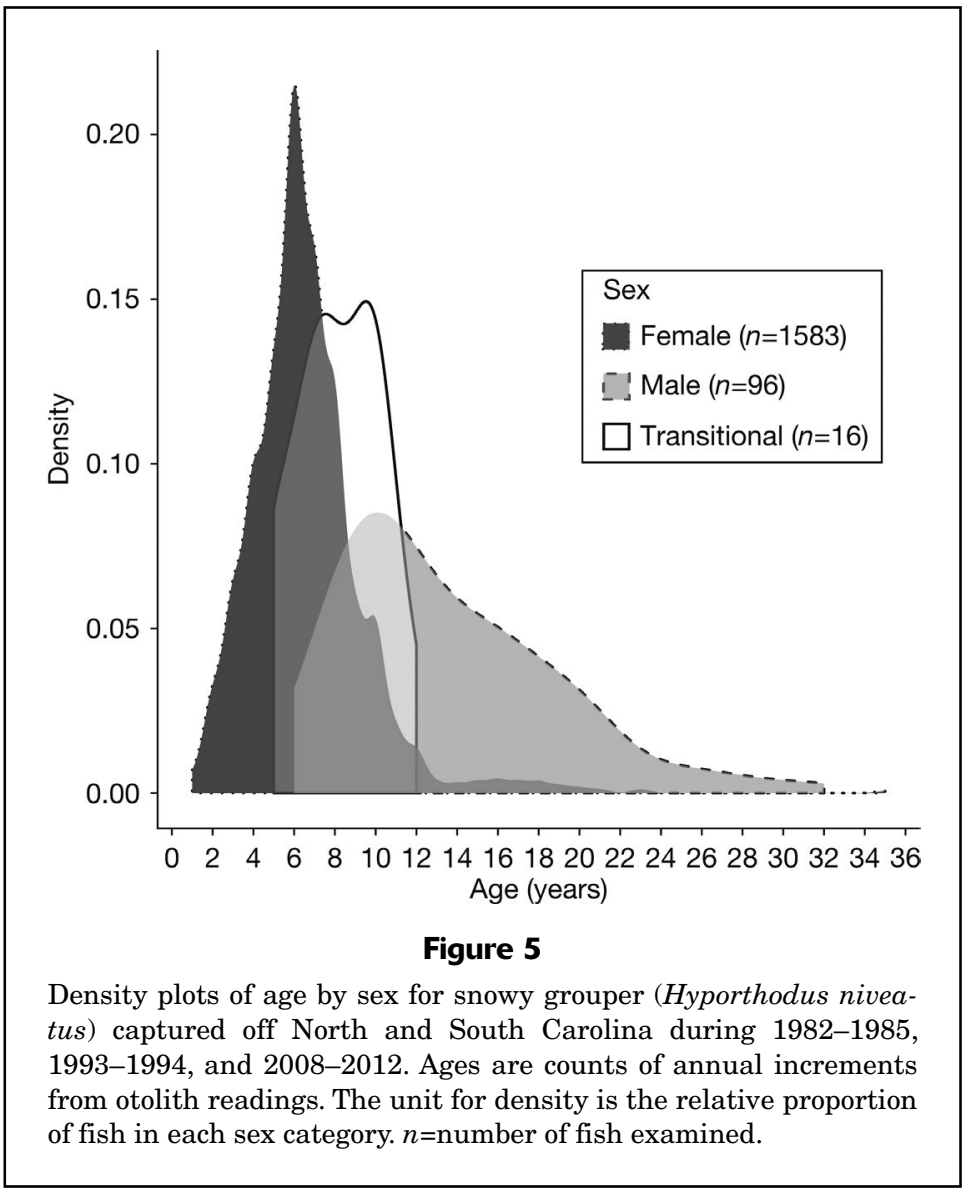

However, overfishing, when the fishing mortality rate is greater than the fishing morality rate at MSY, occurred only once in the last 6 years (2007-2012) of the assessment period, after sustained overfishing that had been happening since the mid-1970s. In the previous assessment conducted in 2004, the population was found to be both overfished and undergoing overfishing (SEDAR, 2004).

\section{Age and growth}

The results of this study indicate that there were noticeable differences in both size and age distributions over time. Results of our analyses indicate that the population has responded more quickly size-wise than age-wise. Density plots of size during each period show a substantial shift to smaller individuals $(<500 \mathrm{~mm} \mathrm{TL})$ from the 1980 s to the 1990 s, with a lower number of larger individuals ( $>800 \mathrm{~mm}$ TL) during the 1990s (Fig. 2A). However, data from the 2000s reveal a symmetrical bell-shaped curve that encompasses both smaller and larger individuals. A population in which all size classes are represented would be better able to respond to factors that influence survivorship and recruitment, and the snowy grouper population is trending in that direction. The age distributions are not as encouraging. The number of older individuals ( $>10$ years) decreased dramatically in the population from the $1980 \mathrm{~s}$

from snowy grouper captured during 2008-2012 revealed evidence of population recovery. Since the mid-1990s, SSB has increased gradually, but the biomass target has not been reached as of the terminal year of 2012 (SEDAR, 2013). to the 1990s. In addition, although there was a slight increase in the proportion of older individuals from the 1990 s to the 2000 s, the low number of older individuals is of concern (Fig. 2B). A higher proportion of older 


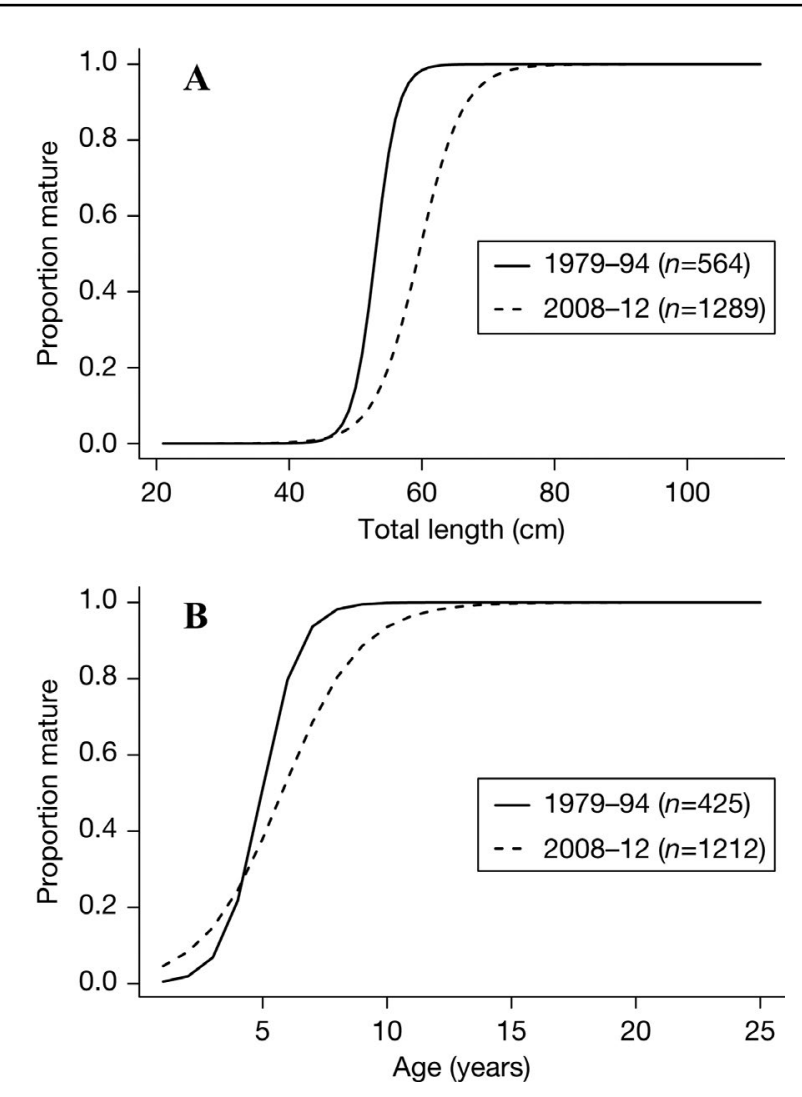

Figure 6

Proportion of female snowy grouper (Hyporthodus niveatus) that were mature, by $(\mathbf{A})$ total length and $(\mathbf{B})$ age. Ages are counts of annual increments from otolith readings. Specimens were collected off North and South Carolina during 1979-1994 and 2008-2012. For size at maturity from the generalized linear model (GLM), the predicted intercept and slope are -35.51 (standard error [SE] 7.45) and 0.066 (SE 0.014), respectively, for 1979-1994 and -17.36 (SE 1.06) and 0.029 (SE 0.002), respectively, for 2008-2012. For age at maturity from the GLM, the predicted intercept and slope are -5.52 (SE1.07) and 1.130 (SE 0.195), respectively, for 1979-1994 and -3.15 (SE 0.28) and 0.566 (SE 0.044), respectively, for 2008-2012. $n=$ number of fish examined.

individuals may be detected if the population is given more time to recover.

The size at age of snowy grouper rose sharply from the 1980s to the 1990s during a time of heavy fishing pressure, but size at age declined in the 2000s once regulations were implemented (Fig. 3). Wyanski et al. (2000) speculated that the increase in the size at age of snowy grouper in the 1990s was the result of moderate to high fishing pressure. Increases in size at age have also been observed for other species, including the gag (Mycteroperca microlepis), the red grouper (Epinephelus morio), and the red porgy (Pagrus pagrus), that were experiencing moderate to high levels of exploitation off the coasts of the southeastern United States in the
Atlantic Ocean and Gulf of Mexico (Johnson et al., 1993; Johnson and Collins, 1994; Harris and McGovern, 1997). The significant reversal of this trend from the 1990s to the $2000 \mathrm{~s}$ is a positive sign for the population of snowy grouper off North and South Carolina. We detected only slight differences in the von Bertalanffy growth parameters between periods, because of the low number of specimens at ages $>15$ years ( 21 specimens in the 1990 s, 9 specimens in the 2000s; Fig. 3).

\section{Reproduction}

Although Moore and Labisky (1984) and Wyanski et al. (2000) presented evidence of protogynous hermaphroditism in snowy grouper, that evidence was not conclusive. In both studies, males were reported to have represented older fish, with ages of 6-27 years (Moore and Labisky, 1984) and ages of 8-29 years (Wyanski et al., 2000). Aspects of population structure (e.g., size distributions and sex composition) generally are not reliable indicators of sexual pattern (Sadovy and Shapiro, 1987); however, a bimodal agefrequency distribution (i.e., males are older than females) is less problematic. The following features of gonad morphology strongly indicate protogyny, as described by Sadovy and Shapiro (1987): 1) membrane-lined central cavities in testes; 2), in transitional individuals, gonads that contain degenerating tissue of one sex and proliferating tissue of the other sex; and 3) atretic bodies within testes that are clearly derived from atretic vitellogenic oocytes, and sperm sinuses in the gonadal wall.

Wyanski et al. (2000) concluded that the presence of primary growth oocytes in 2 gonads with predominantly male tissue and membrane-lined central cavities was indicative of a nearly completed sex transition, but evidence of atretic $(\alpha$-stage) vitellogenic oocytes and sperm sinuses was not present in the samples they analyzed. We met the criteria set by Sadovy and Shapiro (1987) in 2 specimens caught in August 2008 (Fig. 4). An additional criterion, laboratory observations of functional sex change in identified individuals, put forward by Sadovy de Mitcheson and Liu (2008) has yet to be observed in snowy grouper. We noted that 18 specimens were undergoing sex transition, and most (16) of those fish were collected during the spawning season. In contrast, low numbers of transitional specimens in samples collected during the spawning season led Moore and Labisky (1984) and Wyanski et al. (2000) to speculate that transition likely occurs during the non-spawning period. More samples need to be collected outside the spawning season (April-September) to clearly determine the timing of sex transition.

There was also a significant increase in $L_{50 \text {, mat }}$ from the combined value for the $1980 \mathrm{~s}$ and $1990 \mathrm{~s}$ (529 mm TL) to the value for the 2000 s ( $596 \mathrm{~mm}$ TL), a potentially densitydependent reaction (Rothschild, 1986) that is an indication of some recovery (Fig. 6A). Changes between periods in $A_{50 \text {, mat }}$ were similar to results for $L_{50 \text {, mat }}$. Values increased by almost a year from the combined $A_{50 \text {, mat }}$ for the $1980 \mathrm{~s}$ and $1990 \mathrm{~s}$ ( 5.0 years) to that for the $2000 \mathrm{~s}$ (5.8 years), a significant difference (Fig. 6B). 


\section{Table 5}

Proportion of snowy grouper (Hyporthodus niveatus) caught off North and South Carolina that were male, by total length and period. Specimens were collected during the spawning season (April-September) in 3 periods: 1982-1985, 1993-1994, and 2008-2012. Data were combined for 3 gear types: Kali pole, long bottom longline, and short bottom longline. Transitional specimens were considered males because they likely would have spawned as males in their next spawning season. $n=$ number of fish examined.

\begin{tabular}{|c|c|c|c|c|c|c|}
\hline \multirow[b]{2}{*}{$\begin{array}{l}\text { Total } \\
\text { length }(\mathrm{mm})\end{array}$} & \multicolumn{2}{|r|}{$1980 \mathrm{~s}$} & \multicolumn{2}{|r|}{$1990 \mathrm{~s}$} & \multicolumn{2}{|r|}{$2000 \mathrm{~s}$} \\
\hline & $n$ & $\begin{array}{l}\text { Proportion } \\
\text { male }\end{array}$ & $n$ & $\begin{array}{c}\text { Proportion } \\
\text { male }\end{array}$ & $n$ & $\begin{array}{c}\text { Proportion } \\
\text { male }\end{array}$ \\
\hline $401-500$ & & & & & 1 & 0.00 \\
\hline $501-600$ & 6 & 0.00 & 23 & 0.00 & 85 & 0.00 \\
\hline $601-700$ & 32 & 0.00 & 33 & 0.00 & 302 & 0.01 \\
\hline $701-800$ & 40 & 0.00 & 16 & 0.06 & 267 & 0.03 \\
\hline $801-900$ & 29 & 0.38 & 3 & 0.00 & 97 & 0.32 \\
\hline $901-1000$ & 26 & 0.73 & 0 & 0.00 & 34 & 0.62 \\
\hline $1001-1100$ & 6 & 0.83 & 0 & 0.00 & 7 & 0.86 \\
\hline
\end{tabular}

\section{Table 6}

Proportion of adult female (active and inactive) snowy grouper (Hyporthodus niveatus) that were spawning daily, by $100-\mathrm{mm}$ bin for total length. Specimens were collected during spawning season (April-September) off North and South Carolina in 1979-2012. Spawners had at least one indicator of imminent or recent spawning (i.e., oocyte maturation, ovulated eggs, or postovulatory complexes). Sampling period is the time (in days) from which representative samples of data were taken. Values of spawning proportion have been proportionally reduced to a 24 -h period.

\begin{tabular}{lccccrr}
\hline $\begin{array}{l}\text { Total length } \\
\text { bin }(\mathrm{mm})\end{array}$ & $\begin{array}{c}\text { Adult } \\
\text { females }(n)\end{array}$ & $\begin{array}{c}\text { Spawning } \\
\text { proportion } \\
(24 \mathrm{~h})\end{array}$ & $\begin{array}{c}\text { Sampling } \\
\text { period (d) }\end{array}$ & $\begin{array}{c}\text { Spawning } \\
\text { season } \\
\text { duration (d) }\end{array}$ & $\begin{array}{c}\text { Spawning } \\
\text { interval (d) }\end{array}$ & $\begin{array}{c}\text { No. of } \\
\text { batches }\end{array}$ \\
\hline $501-600$ & 130 & 0.06 & 178 & 139 & 17.1 & 8 \\
$601-700$ & 326 & 0.13 & 178 & 153 & 8.0 & 19 \\
$701-800$ & 325 & 0.14 & 178 & 177 & 7.0 & 25 \\
$801-900$ & 94 & 0.17 & 175 & 163 & 6.0 & 27 \\
$\geq 901$ & 26 & 0.18 & 171 & 129 & 5.4 & 24 \\
Total & 901 & 0.13 & & 152 & 7.8 & 19 \\
\end{tabular}

The spawning seasonality observed in our study is broader than that previously reported for the study area and varies with size and age. That 5 specimens with spawning indicators were collected from October 2008 through March 2009 reveals that at least some snowy grouper can have a longer spawning season than the season of April-September reported by Wyanski et al. (2000). Spawning in October also was reported by Kowal (2010), on the basis of capture of snowy grouper with mature oocytes (i.e., undergoing oocyte maturation) in south Florida and the Florida Keys. It remains unknown if spawning in the fall and winter occurs regularly. Spawning by smaller and younger fish $(<600 \mathrm{~mm}$ TL and $<5$ years) tended to occur later in the season and for a shorter period than spawning by larger and older fish (Fig. 7). Larger and older (701-900 mm TL and $\geq 5$ years) individuals had a longer spawning season, and a high proportion of them were spawning throughout the season; therefore, they can produce more batches within the spawning season.

This information is essential for accurate estimates of reproductive potential in the population of snowy grouper off North and South Carolina and indicates that the larger, older females are of greatest importance in reproductive output of this population. Although the spawning proportion increased as individuals grew larger, the duration of the spawning season decreased at sizes $>801 \mathrm{~mm}$ TL, a possible indication of female preparation for sex transition. 

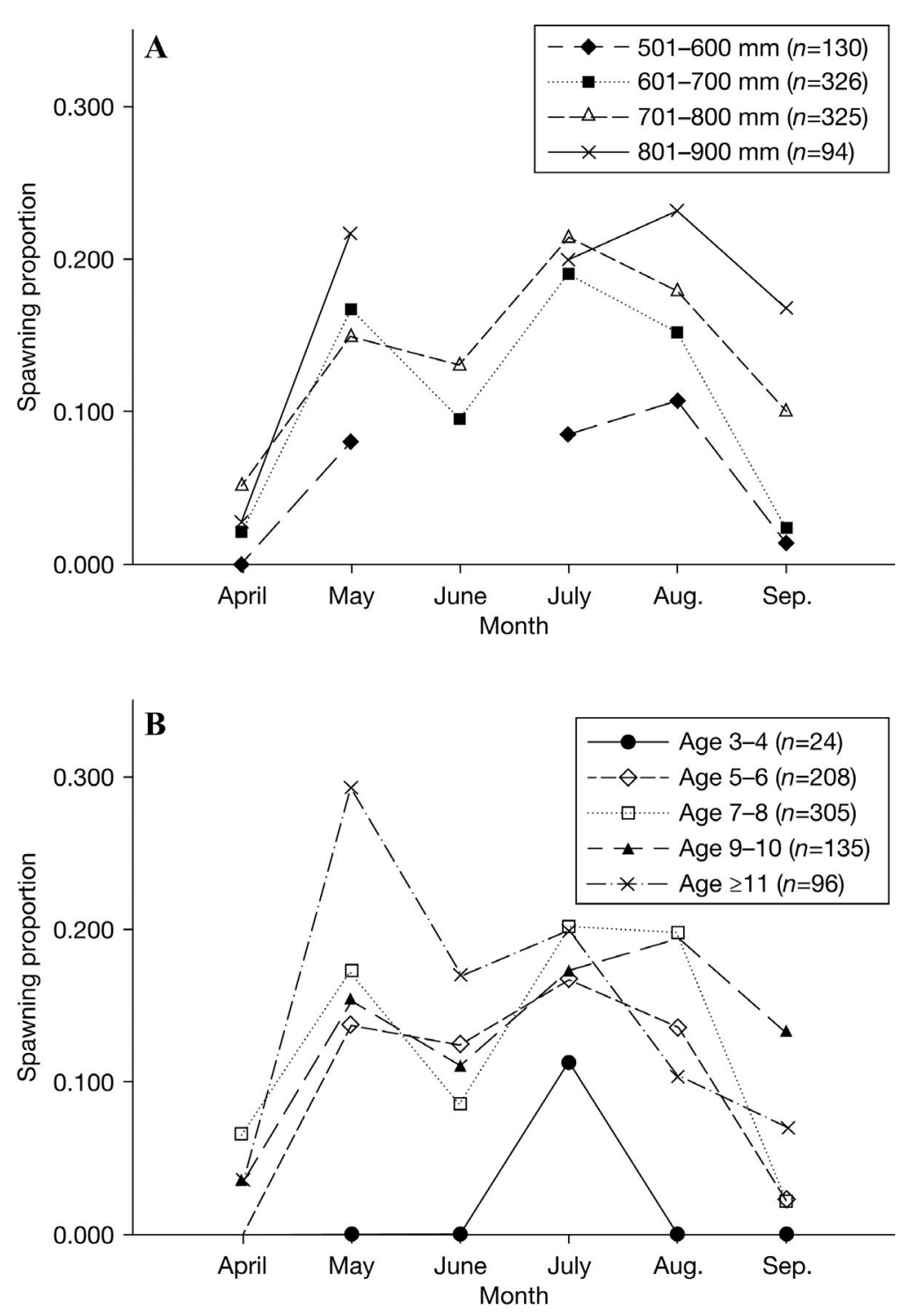

Figure 7

Proportion of adult female (active and inactive) snowy grouper (Hyporthodus niveatus) that were spawning daily, (A) by 100-mm bin for total lengths and (B) by age group (2-year groups for fish 3-10 years old and a terminal group for fish with ages $\geq 11$ years). Note that 2 data points for the month of June in panel A were omitted because of low sample sizes (number of adult females in each group $[n]<10$ ). Specimens were collected off North and South Carolina during spawning season (April-September) in 1979-2012. moderate to strong declines in female spawning frequency relative to age and size in gag and scamp ( $M$. phenax), declines that they also have proposed are linked to increasing future reproductive success as males.

In addition to the effects of size and age, spawning in snowy grouper is influenced by lunar phase. This finding is noteworthy for this grouper species because it inhabits deep waters, where less light reaches during spawning. Spawning of snowy grouper occurs more frequently around the new moon (waning crescent to waxing crescent), when there is less moonlight and possibly less predation on eggs (Fig. 8). It makes intuitive sense that this timing would increase survivorship possibly by affecting larval transport and predation. Farmer et al. (2017) conducted an analysis of monthly relationships between lunar phase and spawning and concluded that spawning in snowy grouper most commonly occurred from June through August during waning crescent to full moon periods by using a data set limited to fishery-independent sources for the period 1990-2013. Results of our study based on aggregated data from a longer period, 1982-2012, and on both fisheryindependent and fishery-dependent sources indicate a different relationship between spawning and lunar phase. We found that the major peak of spawning in snowy grouper occurs within $5 \mathrm{~d}$, before and after, of a new moon. Farmer et al. (2017) also found that snowy grouper exhibit multiyear use of spawning areas, but the resolution of their data was insufficient to confirm the presence of spawning aggregations. This life history characteristic is important and should be investigated further because the presence of spawning aggregations would increase the vulnerability of snowy grouper to fishing and, therefore, would have implications for the management of this species.

These larger, older females may have been saving energetic resources for sex transition and forgone some spawning events. Recent studies of a closely related serranid and 2 grouper species revealed a similar pattern of reduced spawning frequency in larger, older females. Klibansky and Scharf (2018) proposed that decreased egg production prior to sex transition in black sea bass (Centropristis stri$a t a)$ allows females to allocate energy to somatic growth, a switch that would be beneficial during the subsequent male phase. Gamboa-Salazar et al. (2019) observed
The updated information we provide here on life history parameters of snowy grouper supports the notion that the stock off North and South Carolina is in a slow recovery from overfishing. Given that significant plasticity in life history parameters has been observed over time in this population of snowy grouper, continued monitoring of this stock is necessary to assess its status and to allow managers to accurately adjust future regulations, including commercial quotas and trip limits, with the ultimate goal of maintaining the recovery of this stock. 


\section{Table 7}

Proportion of adult female (active and inactive) snowy grouper (Hyporthodus niveatus) that were spawning daily, by age group. Specimens were collected during spawning season (AprilSeptember) off North and South Carolina in 1979-2012. Age groups are based on counts of annual increments from otolith readings. Spawners had at least one indicator of imminent or recent spawning (i.e., oocyte maturation, ovulated eggs, or postovulatory complexes). Sampling period was the time (in days) from which representative samples of data were taken. Values of spawning proportion have been proportionally reduced to a 24 -h period. n/a=not applicable.

\begin{tabular}{rcccccc}
\hline $\begin{array}{l}\text { Age } \\
\text { group }\end{array}$ & $\begin{array}{c}\text { Adult } \\
\text { females }(n)\end{array}$ & $\begin{array}{c}\text { Spawning } \\
\text { proportion } \\
(24 \mathrm{~h})\end{array}$ & $\begin{array}{c}\text { Sampling } \\
\text { period (d) }\end{array}$ & $\begin{array}{c}\text { Spawning } \\
\text { season } \\
\text { duration (d) }\end{array}$ & $\begin{array}{c}\text { Spawning } \\
\text { interval (d) }\end{array}$ & $\begin{array}{c}\text { No. of } \\
\text { batches }\end{array}$ \\
\hline $3-4$ & 24 & 0.03 & 160 & 1 & $\mathrm{n} / \mathrm{a}$ & $\mathrm{n} / \mathrm{a}$ \\
$5-6$ & 208 & 0.11 & 178 & 130 & 8.8 & 15 \\
$7-8$ & 305 & 0.14 & 178 & 165 & 7.1 & 23 \\
$9-10$ & 135 & 0.15 & 175 & 159 & 6.6 & 24 \\
$11-35$ & 96 & 0.14 & 175 & 157 & 7.3 & 22 \\
Total & 768 & 0.13 & & 153 & 7.6 & 20 \\
& & & & & &
\end{tabular}

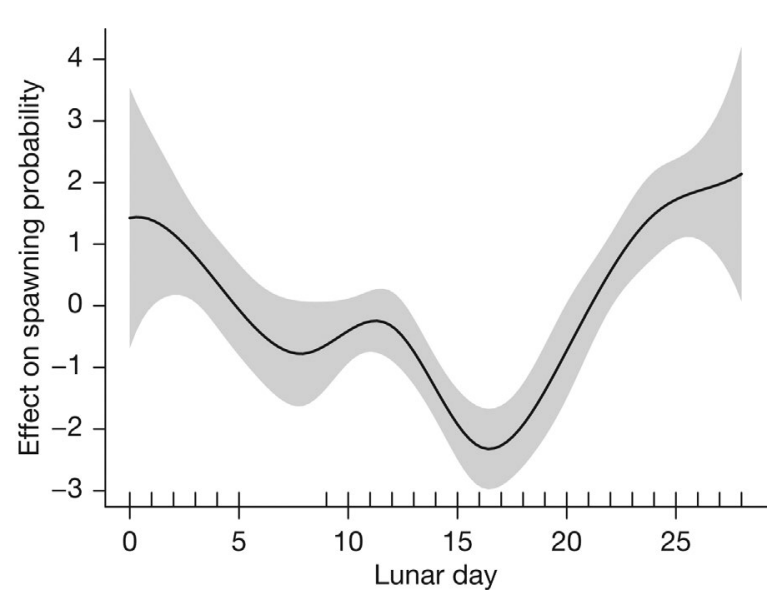

Figure 8

Effect on spawning probability in female snowy grouper (Hyporthodus niveatus) by lunar day from the use of the generalized additive model with a binomial error distribution. The gray area represents $95 \%$ confidence intervals. Tick marks above the $\mathrm{x}$-axis line represent days for which data were available. The new moon day was defined as day 0 , and the full moon was defined as day 15 . Data used in the model came from specimens $(n=371)$ captured during the spawning seasons (April-September) in 19812012 off North and South Carolina.

\section{Acknowledgments}

We sincerely appreciate the efforts of all personnel with the partners (MARMAP, SEAMAP-SA, and SEFIS) of the Southeast Reef Fish Survey, research vessels, Little River Fish House, and Carolina Seafood to collect and process samples. Special thanks go to Captain S. Shelley, F/V Mollie $D$, for collaborating with us. Funding was provided by the NOAA Cooperative Research Program, MARMAP Program (NA11NMF4540174), and SEAMAP-SA Reef Fish Complement (NA11NMF4350043). This is contribution no. 805 of the South Carolina Marine Resources Center.

\section{Literature cited}

Akaike, H.

1973. Information theory as an extension of the maximum likelihood principle. In Second international symposium on information theory (B. N. Petrov and F. Csaki, eds.), p. 267-281. Akademiai Kiado, Budapest.

Brown-Peterson, N. J., D. M. Wyanski, F. Saborido-Rey, B. J.

Macewicz, and S. K. Lowerre-Barbieri.

2011. A standardized terminology for describing reproductive development in fishes. Mar. Coast. Fish. 3:52-70. Crossref

Coleman, F. C., C. C. Koenig, and L. A. Collins.

1996. Reproductive styles of shallow-water groupers (Pisces: Serranidae) in the eastern Gulf of Mexico and the consequences of fishing spawning aggregations. Environ. Biol. Fish. 47:129-141. Crossref

Collins, M. R.

1990. A comparison of three fish trap designs. Fish. Res. 9:325-332. Crossref

Farmer, N. A., W. D. Heyman, M. Karnauskas, S. Kobara, T. I. Smart, J. C. Ballenger, M. J. M. Reichert, D. M. Wyanski, M. S. Tishler, K. C. Lindeman, et al.

2017. Timing and locations of reef fish spawning of the southeastern United States. PLoS ONE 12(3):e0172968. Crossref Federal Register.

2009. Fisheries of the Caribbean, Gulf of Mexico, and South Atlantic; snapper-grouper fishery off the southern Atlantic states; Amendment 15B; reef fish fishery of the Gulf of Mexico. Fed. Regist. 74:58902-58914. 
Fitzhugh, G. R., B. A. Thompson, and T. G. Snider III.

1993. Ovarian development, fecundity, and spawning frequency of black drum Pogonias cromis in Louisiana. Fish. Bull. 91:244-253.

Gamboa-Salazar, K. R., D. M. Wyanski, W. J. Bubley, and N. Klibansky.

2019. Effects of age and size on spawning and egg production in gag and scamp grouper off the southeastern United States. ICES J. Mar. Sci. fsz174. Crossref

Harris, P. J., and J. C. McGovern.

1997. Changes in the life history of the red porgy, Pagrus pagrus, from the southeastern United States, 1972-1994. Fish. Bull. 95:732-747.

Harris, P. J., D. M. Wyanski, D. B. White, and J. L. Moore. 2002. Age, growth, and reproduction of scamp, Mycteroperca phenax, in the southwestern North Atlantic, 1979-1997. Bull. Mar. Sci. 70:113-132.

Harris, P. J., D. M. Wyanski, and P. T. Powers Mikell.

2004. Age, growth, and reproductive biology of blueline tilefish along the southeastern coast of the United States, 1982-1999. Trans. Am. Fish. Soc. 133:1190-1204. Crossref

Heemstra, P. C., W. D. Anderson Jr., and P. S. Lobel.

2002. Serranidae. In The living marine resources of the Western Central Atlantic. Vol. 3: bony fishes part 2 (Opistognathidae to Molidae), sea turtles and marine mammals (K. E. Carpenter, ed.), p. 1308-1369. FAO species identification guide for fishery purposes and American Society of Ichthyologists and Herpetologists Spec. Publ. 5. FAO, Rome.

Hunter, J. R., and S. R. Goldberg.

1980. Spawning incidence and batch fecundity in northern anchovy, Engraulis mordax. Fish. Bull. 77:641-652.

Huntsman, G. R., J. Potts, R. W. Mays, and D. Vaughan. 1999. Groupers (Serranidae, Epinephelinae): endangered apex predators of reef communities. Am. Fish. Soc. Symp. 23:217-231.

Johnson, A. G., and L. A. Collins.

1994. Age-size structure of red grouper, (Epinephelus morio), from the Eastern Gulf of Mexico. Northeast Gulf Sci. 13:101-106. Crossref

Johnson, A. G., L. A. Collins, and J. J. Isley.

1993. Age-size structure of gag, Mycteroperca microlepis, from the northeastern Gulf of Mexico. Northeast Gulf Sci. 13:59-63. Crossref

Klibansky, N., and F. S. Scharf.

2018. Fecundity peaks prior to sex transition in a protogynous marine batch spawning fish, black sea bass (Centro-

Kowal, K. pristis striata). ICES J. Mar. Sci. 75:1042-1053. Crossref

2010. Aspects of the life history of the snowy grouper, Epinephelus niveatus, in the Gulf of Mexico. M.S. thesis, $70 \mathrm{p}$. Univ. South Fla., Tampa, FL.

Lowerre-Barbieri, S. K., K. Ganias, F. Saborido-Rey, H. Murua, and J. R. Hunter.

2011. Reproductive timing in marine fishes: variability, temporal scales, and methods. Mar. Coast. Fish. 3:71-91. Crossref
Matheson, R. H., III, and G. R. Huntsman.

1984. Growth, mortality, and yield-per-recruit models for speckled hind and snowy grouper from the United States South Atlantic Bight. Trans. Am. Fish. Soc. 113:607-616. Crossref

Moore, C. M., and R. F. Labisky.

1984. Population parameters of a relatively unexploited stock of snowy grouper in the lower Florida Keys. Trans. Am. Fish. Soc. 113:322-329. Crossref

Parker, R. O., Jr., and R. W. Mays.

1998. Southeastern U.S. deepwater reef fish assemblages, habitat characteristics, catches, and life history summaries. NOAA Tech. Rep. NMFS 138, 41 p.

$\mathrm{R}$ Core Team.

2013. R: a language and environment for statistical computing. R Foundation for Statistical Computing, Vienna, Austria. [Available from website, accessed February 2018.]

Rothschild, B. J.

1986. Dynamics of marine fish populations, 277 p. Harvard Univ. Press, Cambridge, MA.

RStudio.

2018. RStudio: integrated development environment for R. RStudio Inc., Boston, MA. [Available from website, accessed February 2018.]

Russell, G. M., E. J. Gutherz, and C. A. Barans.

1988. Evaluation of demersal longline gear off South Carolina and Puerto Rico with emphasis on deep-water reef fish stocks. Mar. Fish. Rev. 50(1):26-31.

Sadovy, Y., and D. Y. Shapiro.

1987. Criteria for the diagnosis of hermaphroditism in fishes. Copeia 1:136-156.

Sadovy de Mitcheson, Y., and M. Liu.

2008. Functional hermaphroditism in teleosts. Fish Fish. 9:1-43. Crossref

Scott, W. B., and M. G. Scott.

1988. Atlantic fishes of Canada. Can. Bull. Fish. Aquat. Sci. $219,731 \mathrm{p}$.

SEDAR (Southeast Data, Assessment, and Review).

2004. SEDAR 4-stock assessment report 1: stock assessment of the deepwater snapper-grouper complex in the South Atlantic, 574 p. SEDAR, North Charleston, SC. [Available from website.]

2013. SEDAR 36-South Atlantic snowy grouper stock assessment report, 141 p. SEDAR, North Charleston, SC. [Available from website.]

von Bertalanffy, L.

1938. A quantitative theory of organic growth (Inquiries on growth laws. II). Hum. Biol. 10:181-213.

Wyanski, D. M., D. B. White, and C. A. Barans.

2000. Growth, population age structure, and aspects of the reproductive biology of snowy grouper, Epinephelus niveatus, off North Carolina and South Carolina. Fish. Bull. 98:199-218. 